\title{
Analisis Pakan pada Budidaya Ikan Lele (Clarias Sp.) di Mranggen
}

\author{
Feed Analysis of Cultivation Catfish (Clarias sp.) in Mranggen
}

\author{
Iin Muntafiah \\ Program Studi Pendidikan Biologi, Fakultas Pendidikan Matematika Ilmu Pengetahuan Alam dan \\ Teknologi Informasi \\ Universitas PGRI Semarang \\ Jl. Sidodadi Timur No 24, Dr. Cipto Semarang 50125 Jawa Tengah \\ email: iinmuntafiah21@gmail.com
}

\begin{abstract}
DOI;
ABSTRAK
Pakan merupakan salah satu komponen penting yang dapat 10.30595/jrst.v4i1.6129 menunjang pertumbuhan serta kelangsungan hidup ikan lele. Tujuan penelitian ini untuk mengetahui jenis pakan yang digunakan dalam

Histori Artikel: budidaya ikan lele di Mranggen. Penelitian ini dilakukan pada bulan Desember 2019. Metode yang digunakan dalam penelitian ini metode

Diajukan:

$17 / 12 / 2019$ deskriptif kualiatif, pengambilan sampel menggunkan metode survai. Pengumpulan responden menggunakan random sampling, pengumpulan data menggunakan teknik wawancara dengan responden berjumlah 4

Direvisi:

$02 / 01 / 2020$ orang. Hasil penelitian menunjukkan bahwa pembudidaya menggunakan pakan berupa pelet sebagai pakan utama dan berbagai pakan alternatif berupa ayam tiren, dedak dan maggot. Kandungan protein pelet berkisar

Diterima:

$20 / 03 / 2020$ $25-30 \%$ tergantung jenis pelet yang digunakan. Penggunaan bahan baku lokal berupa dedak memiliki kandungan protein 14,5 - 30\%, sehingga belum dapat mendukung pertumbuhan lele secara maksimal. Penggunaan bahan baku ayam tiren mampu menekan biaya produksi ikan lele, namun kandungan gizinya tidak dapat terjaga. Maggot berpotensi sebagai pakan lele karena memiliki kandungan protein yang tinggi yaitu 30 - 40\% serta pemeliharaannya mudah.
\end{abstract}

Kata Kunci: Pakan, Budidaya, Ikan lele

\begin{abstract}
Feed is one of the important components that can support the growth and survival of catfish. The purpose of this study was to determine the type of feed used in catfish farming in Mranggen. This research was conducted in December 2019. The method used in this study was a qualitative descriptive method, sampling using the survey method. The collection of respondents using random sampling, data collection using interview techniques with respondents totaling 4 people. The results showed that the farmers used pellet feed as the main feed and various alternative feeds in the form of chicken, bran and maggot. The protein content of pellets ranges from $25-30 \%$ depending on the type of pellet used. The use of local raw materials in the form of bran has a protein content of $14.5-30 \%$, so it has not been able to support the growth of catfish to the fullest. The use of raw chicken ingredients can reduce the cost of catfish production, but the nutritional content cannot be maintained. Maggot has the potential as catfish feed because it has a high protein content that is $30-40 \%$ and easy maintenance.
\end{abstract}

Keywords: Feed, Cultivation, Catfish 


\section{PENDAHULUAN}

Ikan lele merupakan salah satu sektor perikanan yang unggul dipasaran dan memiliki potensi dalam ketahanan pangan sebagai sumber protein hewani. Prospek ikan lele begitu menjanjikan dari segi permintaan dan juga harga jualnya. Keunggulan ikan lele diantaranya yaitu pertumbuhannya tergolong cepat, toleran terhadap penyakit dan kualitas air yang kurang baik serta dapat dipelihara hampir pada semua wadah budi daya. Menurut data Dirjen Perikanan Budidaya (2015) produksi nasional ikan lele dari tahun 2015 hingga tahun 2019 ditargetkan dapat mengalami peningkatan dari 1.058 .400 pada tahun 2015 meningkat pada tahun 2019 hingga sebesar 1.779.900 (Mustajib et al., 2018).

Minat masyarakat untuk mengonsumsi ikan lele sebagai sumber protein hewani cukup banyak, hal ini karena ikan lele memiliki harga yang terjangkau, pengolahannya mudah, dan memiliki rasa yang enak (Wardhani et al., 2017). Tingginya minat masyarakat terhadap komoditas ikan lele mendorong pelaku usaha budidaya untuk mengupayakan produksi dengan maksimal. Upaya yang dapat dilakukan oleh pembudidaya untuk meningkatkan produksi ikan lele yaitu dengan mengoptimalkan kualitas dan efisiensi pakan yang dapat mendukung hasil produksi ikan lele.

Pakan merupakan komponen penting dalam budidaya ikan lele untuk menunjang pertumbuhan serta kelangsungan hidup ikan budidaya. Pakan komersial saat ini memiliki harga yang tinggi sehingga pelaku usaha budidaya ikan tawar dapat menghabiskan biaya mencapai $75 \%$ dari total biaya yang dibutuhkan untuk budidaya (Wardani et al., 2017).

Tingginya harga pakan ini karena penggunaan bahan baku pakan pabrik pelet merupakan komoditas impor sehingga menekan biaya yang besar bagi para pembudidaya ikan lele. Mahalnya harga pakan mengakibatkan keuntungan yang diperoleh pembudidaya tidak maksimal bahkan dapat merugi. Pemberian pakan juga harus memperhatikan kualitas dan kuantitas, sehingga sesuai dengan kebutuhan gizi yang diperlukan oleh ikan. Pakan yang berkualitas memiki kandungan nutrisi yang lengkap, mudah dicerna oleh ikan dan tidak mengandung zat-zat berbahaya bagi ikan (Yunaidi et al., 2019) .

Penelitian ini bertujuan untuk mengetahui jenis pakan yang digunakan dalam budidaya ikan lele di Mranggen. Penelitian ini diharapkan dapat memberikan informasi ilmiah kepada masyarakat khususnya bagi para pelaku usaha budidaya ikan lele mengenai pakan yang berkualitas yaitu memiliki kandungan nutrisi yang lengkap dengan harga yang ekonomis sehingga dapat meningkatkan produktivitas ikan lele.

\section{METODE PENELITIAN}

\subsection{Waktu dan Tempat}

Penelitian ini dilakukan pada tanggal 8 Desember 2019 yaitu dengan melakukan wawancara dengan pembudidaya ikan lele sebanyak 4 responden yang ada di desa Mranggen, Kabupaten Demak.

\subsection{Subjek Penelitian}

Subjek penelitian ini adalah berbagai pakan yang digunakan dalam budidaya ikan lele.

\subsection{Prosedur Penelitian}

Metode yang digunakan dalam penelitian adalah metode deskriptif kualitatif. metode deskriptif yaitu metode yang berpusat pada pemecahan masalah yang ada saat ini dan masalah-masalah aktual. Dalam penelitian menjelaskan permasalahan mengenai jenis pakan yang digunakan dalam budidaya ikan lele. Cara memperoleh data yaitu dengan pengumpulan data, menyusun data, menjelaskan dan menganalisis (Surakhmad, 1994). Pengambilan sampel pada penelitian menggunkan metode survai. Penelitian survei merupakan penelitian yang mengambil sampel dari suatu populasi dan menggunakan kuisioner sebagai alat pengumpulan datanya (Singarimbun dan Effendi, 1998). Populasi dalam penelitian ini yaitu sekelompok pembudidaya lele yang ada di kecamatan Mranggen, kabupaten Demak. Pengumpulan responden pada penelitian ini dilakukan dengan cara random sampling, pengumpulan data menggunakan teknik wawancara berdasarkan daftar pertanyaan yang telah dipersiapkan sebelumnya. Responden berjumlah 4 pembudidaya yang ada di Kecamatan Mranggen, Kabupaten Demak.

\subsection{Penentuan Sampel Responden}

Penentuan responden pada penelitian ini diambil dari kelompok pembudidaya ikan lele yang berada di kecamatan Mranggen, kabupaten Demak. Pada penelitian ini diambil responden sebanyak 4 anggota dari kelompok petani pembudidaya ikan lele yang diambil secara acak (Random Sampling). Pengambilan 
sampel secara random sampling ini berarti setiap anggota kelompok pembudidaya ikan lele memiliki kesempatan yang sama untuk dipilih sebagai sampel.

\subsection{Jenis dan Sumber Data}

\subsubsection{Data Primer}

Data primer yaitu data yang diperoleh secara langsung langsung dari sumber data oleh peneliti. Data primer dalam penelitian ini terkait dengan pakan yang biasanya digunakan oleh responden sebagai pakan lele yang dibudidayakan. Data tersebut diperoleh langsung dari responden melalui wawancara langsung dengan menggunakan kuisioner yang telah dipersiapkan.

\subsubsection{Data Sekunder}

Data sekunder yaitu data yang telah ada terlebih dahulu dikumpulkan dan dilaporkan oleh orang di luar peneliti. Data dicatat secara sistematis dan dikutip secara langsung dari instansi yang terkait dengan penelitian ini. Data sekunder diperoleh dari data hasil penelitian sebelumnya yang mendukung penelitian ini.

\section{HASIL DAN PEMBAHASAN}

Hasil analisis data wawancara keempat responden pembudidaya lele yang ada di kecamatan Mranggen, Kabupaten Demak terkait dengan keefektifan penggunaan pakan pelet disajikan dalam Gambar 1.

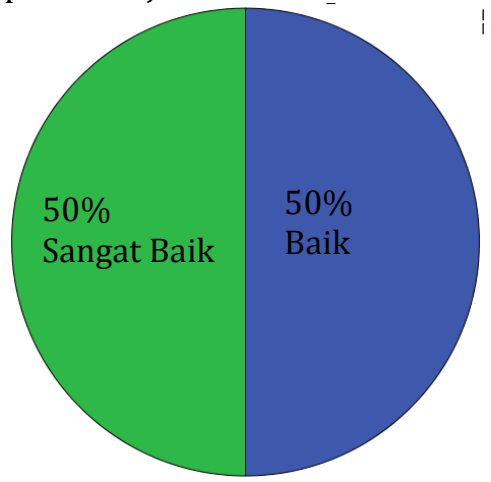

Gambar 1 Keekfetifan penggunaan pakan pelet menurut responden

\section{Keefektifan Penggunaan Pakan Pelet}

Hasil analisis terkait keefektifan penggunaan pakan pelet oleh pembudidaya dihasilkan $50 \%$ responden mengatakan bahwa pakan pelet sangat baik dijadikan sebagai pakan utama dan 50\% responden mengatakan bahwa pakan pelet baik untuk dijadikan pakan utama. Responden menyatakan bahwa dalam budidaya ikan lele mereka menggunakan pakan pelet sebagai pakan utama, namun kendalanya adalah harga pakan pelet saat ini mahal sehingga menjadikan pakan memiliki biaya terbesar dalam produksi. Hal ini sesuai dengan pernyataan dalam Wardani et al., (2017) bahwa pakan memiliki biaya mencapai $75 \%$. Harga pakan pelet tergantung dengan jenis pelet dimana pelet yang memiliki nutrisi lengkap memiliki harga yang relatif mahal yaitu Rp. 10.000 - 13.000/kg dibandingkan dengan harga pakan yang memiliki nutrisi rendah dengan harga Rp. 8.000 - 10.000/kg.

Berdasarkan pernyataan responden, mereka lebih sering menggunakan pakan yang memiliki nutrisi lengkap meskipun memiliki harga yang mahal, hal ini karena apabila menggunakan pakan yang memiliki nutrisi rendah akan menurunkan nafsu makan lele yang akan berakibat pertumbuhan lele terhambat sehingga waktu panen akan semakin lama, selain itu bobot lele juga menurun. Pakan merupakan sumber energi bagi ikan, oleh sebab itu nutrisi yang terkandung dalam pakan harus teraga terutama kandungan protein. Kandungan protein yang ada dalam pakan berpengaruh terhadap tinggi rendahnya pertumbuhan ikan. Ikan dapat tumbuh dengan baik apabila kebutuhan proteinnya mencukupi. Kebutuhan protein ikan lele berkisar 32-35 \% (Watson et al., 2007). Kurangnya protein dalam pakan dapat berpengaruh terhadap pertumbuhan menjadi terhambat dan rendahnya bobot tubuh karena protein pada jaringan tubuh digunakan untuk memelihara fungsi vital sehingga menyebabkan hasil produksi tidak maksimal.

Kualitas pelet bergantung dengan bahan baku yang digunakan. Berdasarkan analisa proksimat menunjukkan kadar abu tepung pelet 33\% dan kandungan protein $30 \%$. Tingginya kadar abu dibandingkan kandungan protein ini karena bahan baku pelet berasal dari limbah ikan rucah mentah yang bagian tulangnya lebih banyak dibandingkan dengan dagingnya (Abidin et al., 2015).

\section{Keefektifan Pakan Alternatif}

Hasil analisis data wawancara keempat responden pembudidaya lele yang ada di kecamatan Mranggen, Kabupaten Demak terkait Keekfetifan penggunaan pakan alternatif menurut responden disajikan dalam Gambar 2. 


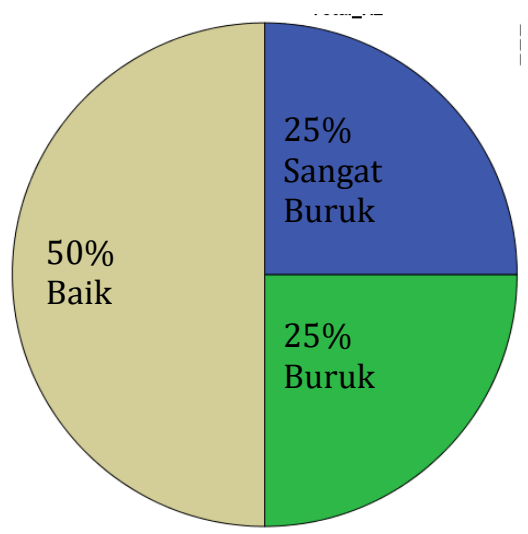

Gambar 2 Keefektifan Pakan Alternatif

Berdasarkan data analisis didapatkan hasil bahwa 25\% responden menyatakan bahwa pakan alternatif sangat buruk atau sangat tidak sesuai digunakan sebagai sumber protein ikan lele, sedangakan 25\% menyatakan bahwa pakan alternatif buruk atau kurang sesuai apabila digunakan sebagai sumber protein bagi ikan lele, dan 50\% responden menyatakan bahwa pakan alternatif baik atau sesuai digunakan sebagai pakan budidaya. Responden menyatakan bahwa pakan alternatif yang mereka gunakan belum efektif digunakan karena kandungan gizi dalam pakan alternatif kurang sesuai dengan kebutuhan ikan lele.

Pakan alternatif yang digunakan oleh responden antara lain dedak, ayam tiren dan maggot. 50\% responden menyatakan bahwa biasanya menggunakan pakan tambahan berupa ayam tiren sebagai pengganti pelet, namun terdapat kendala dalam penggunaan pakan ini yaitu pengolahan menjadi pakan memerlukan waktu yang lama serta kandungan nutrisi pada pakan berbahan dasar ayam tiren ini tidak terjaga kandungan gizinya, hal akan berdampak pada kualitas daging yang dihasilkan rendah.

$25 \%$ responden menggunakan dedak halus sebagai pakan alternatif, namun dalam penggunaan dedak sebagai pakan alternatif tidak efektif karena kandungan protein dedak rendah, sehingga belum memenuhi kebutuhan protein bagi ikan lele. Hal ini sesuai dengan hasil penelitian Abidin (2015) penggunaan bahan baku lokal dedak memiliki kandungan protein 14,5 - 30\%, sehigga belum dapat mendukung pertumbuhan lele secara maksimal.

$25 \%$ responden menggunakan pakan maggot sebagai pakan alternatif. Responden menyatakan bahwa maggot berpotensi sebagai pakan alternatif karena memiliki kandungan protein tinggi. Hal ini sesuai dengan pernyataan Wardhana (2016) bahwa maggot berpotensi sebagai sumber protein pakan ternak karena memiliki kandungan protein mencapai 40-50\%. Keuntungan lain selain memiliki kandungan protein tinggi, dari segi ekonomi penggunaan maggot relatif lebih murah dibandingkan pakan pelet. Penggunaan maggot sebagai pakan ikan juga tidak bersaing dengan manusia. Maggot sangat berpotensi sebagai pakan alternatif pakan ikan lele yaitu penggunaan $50 \%$ pelet dan $50 \%$ maggot dapat menghemat biaya pakan mencapai 22,74\% (Fauzi \& Sari, 2018).

Hal yang perlu diperhatikan dalam pemilihan pakan diantaranya kandungan gizinya tinggi dan efisien, sehingga pertumbuhan ikan lele tidak terhambat dan kualitas daging lele yang dihasilkan tinggi. Pemilihan penyediaan pakan tambahan yaitu berdasarkan kandungan nutriennya memenuhi serta memiliki harga yang murah. Pakan yang dapat memenuhi kebutuhan ikan adalah pakan yang memiliki keseimbangan antara protein dengan sumber energi lain non protein (Rachmawati \& Samidjan, 2013). Pakan merupakan salah satu fakor yang sangat pening dalam budidaya ikan, sehingga pakan yang digunakan memiliki beberapa krieria diantaranya kandungan gizinya sesuai dengan kebutuhan ikan, mudah untuk dicerna, ketersediaannya melimpah dan berkesinambungan (Wardani et al., 2017) .

\section{KESIMPULAN}

Pembudidaya ikan lele di Mranggen menggunakan pakan pelet sebagai pakan utama dan menggunakan pakan alternatif berupa ayam tiren, dedak dan maggot. Kandungan protein pelet berkisar $25-30 \%$ tergantung jenis pelet yang digunakan. Kandungan protein dedak berkisar 14,5 - 30\% sehingga belum dapat mendukung pertumbuhan lele secara maksimal. Penggunaan bahan baku ayam tiren mampu menekan biaya produksi, namun kandungan gizinya tidak dapat terjaga. Maggot memiliki kandungan protein yang tinggi yaitu $30-40 \%$ serta pemeliharaannya mudah.

\section{DAFTAR PUSTAKA}

Abidin, Z., Junaidi, M., Cokrowati, N., \& Yuniarti, S. (2015). Pertumbuhan dan Konsumsi Pakan Ikan Lele (Clarias sp .) yang diberi Pakan Berbahan Baku Lokal. 4(April), 33-39. 
Fauzi, R. U. A., \& Sari, E. R. N. (2018). Analisis Usaha Budidaya Maggot sebagai Alternatif Pakan Lele. Jurnal Teknologi dan Manajemen Agroindustri, 7.

Mustajib, Elfitasari, T., \& Chilmawati, D. (2018). Prospek Pengembangan Budidaya Pembesaran Ikan Lele (Clarias sp) di Desa Wonosari, Kecamatan Bonang, Kabupaten Demak. Jurnal Sains Akuakultur Tropis, 2(1), 38-48.

Rachmawati, D., \& Samidjan, I. (2013). Maggot dalam Pakan Buatan terhadap Pertumbuhan Dan Kelulushidupan Ikan Patin ( Pangasius pangasius ). Saintek Perikanan, 9(1).

Wardani, R. E., Prayogo, S.Pi., M., \& Agustono, Ir., M. K. (2017). Potensi Penambahan Azolla $s p$. dalam Formulasi Pakan Pembedahan. Journal of Aquaculture and Fish Health, 6(2).

Wardhana, A. H. (2016). Black Soldier Fly
(Hermetia illucens) sebagai Sumber Protein Alternatif untuk Pakan Ternak. Wartazoa: Buletin Ilmu Peternakan dan Kesehatan Hewan Indonesia, 26(2).

Wardhani, A. K., Sudarno, \& Kusdarwati, R. (2017). Gambaran Histopatologi Kulit dan Insang Benih Ikan Lele (Clarias sp.) yang Terinfeksi Saprolegnia Sp. dan yang Telah Diobati dengan Ekstrak Daun Sirih (Piper betle L.) Histopatologic. Journal of Aquaculture and Fish Health, 7(1).

Watson, V. H., Foglesong, R. H., \& Robinson, E. H. (2007). Catfish Protein Nutrition. Mississippi Agricultural \& Forestry Experiment Station.

Yunaidi, Rahmanta, A. P., Wibowo, A., \& Politeknik. (2019). Aplikasi pakan pelet buatan untuk peningkatan produktivitas budidaya ikan air tawar di desa Jerukagung Srumbung Magelang. urnal Pemberdayaan,3(1) 